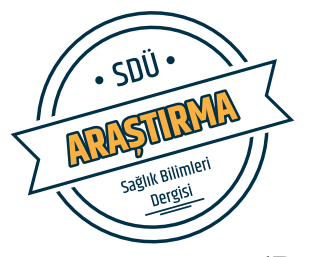

Sdü Sağlık Bilimleri Dergisi / Cilt 10 Sayı 3 / 2019

\title{
The Relation Between The Grade of Coronary Collaterals and Vitamin D Levels
} Vitamin D ile Koroner Kollateral Seviyesi Arasındaki İlişki

${ }^{1}$ Department of Cardiology, University of Health Sciences, Education and Research Hospital, Antalya, Turkey.

${ }^{2}$ Sakarya University, Department of Cardiology, Education and Research Hospital, Sakarya, Turkey.

\begin{abstract}
Objective: There have been studies which revealed a possible relation with the grade of coronary collateral circulation (CCC) and the level of Vitamin D in the literature. The objective of this study was to assess whether there is a correlation between the grade of CCC and the level of Vitamin D according to both Rentrop and Werner classifications in patients with coronary chronic total occlusion (CTO) who underwent percutaneous coronary intervention.
\end{abstract}

Material-Method: The present study is a single-centre, retrospective cohort study. A total of 101 consecutive patients, who were hospitalized to undergo coronary CTO procedure, were enrolled in the study. The patients were classified into 3 groups with regard to the grade of CCC according to both Rentrop and Werner classifications. These groups were compared with each other according to the $25(\mathrm{OH}) \mathrm{VitD}_{3}$ levels.

Results: There was no significant difference among 3 groups with regard to $25(\mathrm{OH}) \mathrm{VitD}_{3}$ levels when the patients were classified according to the Rentrop classification [Rentrop 1: $15.7 \mathrm{ng} / \mathrm{ml}(7.0-77.0 \mathrm{ng} / \mathrm{ml})$, Rentrop 2: $16.9 \mathrm{ng} / \mathrm{ml}(7.0-71.3)$, Rentrop 3: $16.6 \mathrm{ng} / \mathrm{ml}(7.0-28.7), \mathrm{p}=0.925]$. Moreover, there was no significant difference among 3 groups with regard to $25(\mathrm{OH})$ VitD3 levels when the patients were classified according to the Werner classification. [Werner 0: $19.6 \mathrm{ng} / \mathrm{ml}$ (7.0-77.0 ng/ml), Werner 1: $16.6 \mathrm{ng} / \mathrm{ml}$ (7.0-71.3), Werner 2: $17.0 \mathrm{ng} / \mathrm{ml}(7.0-28.3), \mathrm{p}=0.411]$.

Conclusions: We deem that there may not be a direct correlation (one-to-one relationship) between the level of $25(\mathrm{OH}) \mathrm{VitD}_{3}$ and the grade of CCC in clinical practice.

Keywords: Collateral Circulation, Coronary Occlusion, Percutaneous Coronary Intervention, Vitamin D.

\section{Özet}

Amaç: Literatürde koroner kollateral dolaşımın (KKD) derecesi ile D vitamini seviyesi arasında muhtemel bir ilişki olabileceğine dair yayınlar mevcuttur. Bu çalışmanın amacı kronik total oklüzyon (KTO) nedeniyle perkütan koroner girişim yapılan hastalarda hem Rentrop hem de Werner sınıflandırmasına göre KKD ile D vitamini seviyesi arasında bir ilişki olup olmadığının araştırılmasıdır.

Materyal-Metot: Mevcut çalışma tek-merkezli, retrospektif kohort çalışmasıdır. KTO işlemi için hastaneye yatırılan ardışık 101 hasta çalışmaya alınmıştır. Hastalar KKD derecesine göre hem Rentrop hem de Werner sınıflandırmasına göre üçer gruba ayrılmıştır. Her bir grup $25(\mathrm{OH}) \mathrm{VitD}_{3}$ seviyesine göre birbiriyle kıyaslanmıştır.

Bulgular: Hastalar Rentrop sınıflandırmasına göre üç gruba ayrıldığında gruplar arasında $25(\mathrm{OH}) \mathrm{VitD}_{3}$ seviyesi açısından fark saptanmamıştır [Rentrop 1: $15,7 \mathrm{ng} / \mathrm{ml}(7,0-77,0 \mathrm{ng} /$ $\mathrm{ml})$, Rentrop 2: 16,9 ng/ml (7,0-71,3), Rentrop 3: 16,6 ng/ $\mathrm{ml}(7,0-28,7), \mathrm{p}=0,925]$. Hastalar Werner sinıflandırmasina göre tekrar üç gruba sınıflandırıldığında yine gruplar arasında 25(OH)VitD3 seviyesi açısından fark saptanmamıştır [Werner 0: 19,6 ng/ml (7,0-77,0 ng/ml), Werner 1: 16,6 ng/ml (7,071,3), Werner 2: 17,0 ng/ml (7,0-28,3), $\mathrm{p}=0,411]$.

Sonuç: Çalışma sonucuna göre $25(\mathrm{OH}) \mathrm{VitD}_{3}$ seviyesi ile KKD derecesi arasında klinik pratikte bire bir ilişki olmadığı kanaatindeyiz.

Anahtar kelimeler: Koroner dolaşım, Koroner Oklüzyon, Perkütan Koroner Girişim, Vitamin D.

Coronary collateral circulation (CCC) is an alternative vascular conduit which supplies blood to the jeopardized myocardium in case of a critical coronary stenosis. A welldeveloped CCC may limit the infarcted myocardium, preserve myocardial viability and diminish major adverse cardiac events in patients with acute myocardial infarction or stable angina $(6,7)$.

There have been studies which revealed a possible relation with the grade of CCC and the level of Vitamin D in the literature.

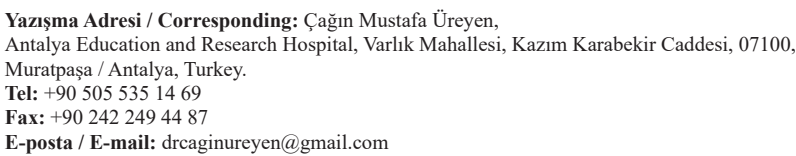


The objective of this study was to assess whether there is a correlation between the grade of CCC and the level of Vitamin $\mathrm{D}$ according to both Rentrop and Werner classifications in patients with coronary chronic total occlusion (CTO) who underwent percutaneous coronary intervention (PCI).

\section{Material and Methods}

\section{Study Design and Patient Population}

The present pilot study is a single-centre, retrospective cohort study. A total of 101 consecutive patients, who were hospitalized to undergo coronary CTO procedure, were enrolled in the study during November 2016 and October 2017. All patients were assessed with blood tests including 25-hydroxy vitamin D3 $\left[25(\mathrm{OH}) \mathrm{VitD}_{3}\right]$ within a week before the CTO procedure. The patients with a history of coronary artery bypass grafting, acute coronary syndrome within the last 3 months, active cancer and active infection as well as patients taking Vitamin D replacement were all excluded from the study.

The patients were classified into 2 groups as poor vs welldeveloped collaterals with regard to the grade of CCC according to both Rentrop and Werner classifications. Rentrop grade 0-1 collaterals and Werner grade 0-1 collaterals were defined as poor collaterals, whilst Rentrop grade 2-3 collaterals and Werner grade 2 collaterals were defined as well-developed collaterals. These 2 groups were compared with each other according to the $25(\mathrm{OH}) \mathrm{VitD}_{3}$ levels. This study complies with the Declaration of Helsinki, and the research protocol was approved by the local ethics committee (IRB approval date: 14/04/2017 and number: 71522473/050.01.04/73).

\section{Laboratory Analysis}

All blood samples were obtained within the last week before the CTO procedure via antecubital vein. $25(\mathrm{OH}) \mathrm{VitD}_{3}$ levels were analysed with a chemiluminescent immunoassay (DiaSorin Saluggia, Italy; Stillwater, MN, USA).

\section{Coronary Angiography and The Evaluation of Ccc}

All coronary procedures were executed using a Toshiba Infinix $8000 \mathrm{~V}$ and Toshiba Infinix 8000G5 (Toshiba Medical Systems, Nasushiobara, Japan). Coronary angiograms were analyzed regarding coronary collateral circulation by 2 independent angiographers who were blinded to the clinical data of the patients. If there was a discrepancy between 2 angiographers, a third blinded angiographer assessed the grade of CCC. CCC was assessed according to Rentrop and Werner classifications. Rentrop classification is graded as: 0 , no collateral circulation; 1 , collateral circulation is limited to the side-branch of the recipient artery; 2, collateral circulation partially fills the recipient epicardial coronary artery; 3, collateral circulation completely fills the recipient epicardial coronary artery (8). Werner classification is graded as: 0 , no visible connection between the donor and the recipient coronary artery; 1 , thread-like connection between the donor and the recipient coronary artery; 2, side-branch like connection between the donor and the recipient coronary artery (9).

\section{Statistical Analysis}

Data analyses were performed by using Statistical Package for Social Sciences (SPSS) for Windows 24 package program (SPSS Inc, Chicago IL, USA). Variables were assessed using visual and analytical methods (Kolmogorov-Simirnov test) to determine whether they were normally distributed. A Mann-Whitney U test was used to compare medians, while student's t-rest was used to compare means in different groups. The Chi-square test was used to compare proportions and percentages in different groups. The associations among the total cholesterol, LDL cholesterol, the distribution of the occluded artery, and the $25(\mathrm{OH}) \mathrm{VitD}_{3}$ level were assessed using the Spearman correlation. A p-value of less than 0.05 was considered to show a statistically significant result.

\section{Results}

A total of 101 patients were enrolled in the study. These patients were classified according to both Rentrop and Werner classifications.

\section{Rentrop Classification}

The baseline characteristics of the patients which were classified according to the Rentrop classification as poor collaterals and well-developed collaterals were shown in Table 1. There was no significant difference among 2 groups with regard to $25(\mathrm{OH}) \mathrm{VitD}_{3}$ levels. [Poor collaterals: $14.8 \mathrm{ng}$ / $\mathrm{ml}$ (7.0-77.0), well-developed collaterals: $16.6 \mathrm{ng} / \mathrm{ml}$ (7.071.3), $\mathrm{p}=0.699$ ]. Among the baseline characteristics, the total cholesterol and LDL cholesterol were significantly higher in patients with poor collaterals. Therefore, a univariate analysis was performed whether there was a correlation among the total cholesterol, LDL cholesterol, and $25(\mathrm{OH}) \mathrm{VitD}_{3}$ level. The univariate analysis revealed that $25(\mathrm{OH}) \mathrm{VitD}_{3}$ level was not associated with the total cholesterol and LDL cholesterol ( $\mathrm{p}=0.777$ and $\mathrm{p}=0.380$, respectively).

\section{Werner Classification}

The baseline characteristics of the patients which were classified according to the Werner classification as poor collaterals and well-developed collaterals were shown in Table 2. There was no significant difference among 2 groups with regard to $25(\mathrm{OH}) \mathrm{VitD}_{3}$ levels when the patients were classified according to the Werner classification. [Poor collaterals: 16.4 (7.0-77.0), well-developed collaterals: $16.7 \mathrm{ng} / \mathrm{ml}$ (7.8-63.2), $\mathrm{p}=0.336]$. Among the baseline characteristics, the distribution of the occluded artery (the vessel with a CTO lesion) was statistically different between 2 groups. Therefore, a univariate analysis was performed whether there was a correlation between the $25(\mathrm{OH}) \mathrm{VitD}_{3}$ level and the distribution of the occluded artery. The univariate analysis revealed that $25(\mathrm{OH})$ $\mathrm{VitD}_{3}$ level was not associated with the distribution of the occluded artery $(\mathrm{p}=0.466)$.

\section{Discussion}

Coronary collaterals are formed during embryogenesis via the mechanism of vasculogenesis. Development of collaterals after embryogenesis depends on two different mechanisms: angiogenesis and arteriogenesis. Angiogenesis is the formation 
Table 1. Patient characteristics compared according to the Rentrop classification

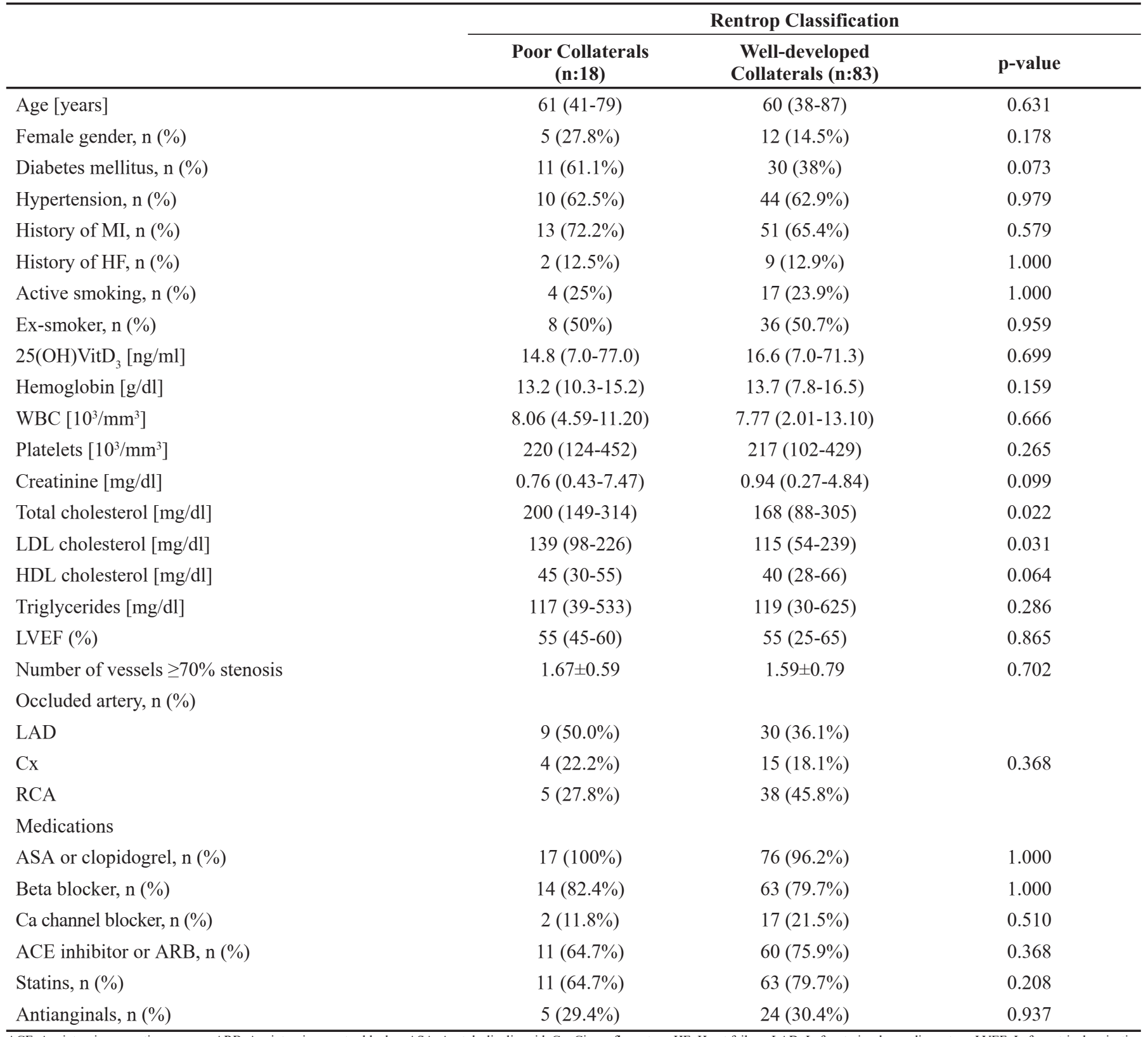

of new capillaries via sprouting of endothelial cells from the pre-existing vessels. This process is basicly driven by vascular endothelial growth factor (VEGF) and basic fibroblast growth factor which are released in response to ischemic conditions. However, arteriogenesis is the structural remodelling of preformed capilleries formed during embryogenesis in response to complete occlusion of the coronary artery. The remodelling of capilleries is mainly driven by the pressure gradient which leads to shear stress on the endothelium. The diameter of the collaterals can increase up to twelve times during positive remodelling (10).

The significance of coronary collaterals are that welldeveloped collaterals can limit the infarction area and may even decrease the mortality $(11,12)$. Moreover, a metaanalysis including 13 trials demonstrated a mortality benefit in patients with well-developed coronary collaterals (13). Thus, revealing the mechanisms of development of coronary collaterals is getting more important. It was ascertained in the previous studies that nitric oxide (NO) and NO synthase play a key role in the process of vasculogenesis (14). In addition to NO pathway, there are experimental studies which demonstrated that vitamin D may promote proliferation and migration of endothelial cells (15). Furthermore, Grundmann et al. stated that vitamin D enhances angiogenic properties of endothelial progenitor cells via regulating the VEGF signalling pathway (16). Moreover, vitamin D has a regulatory effect on more than 200 genes, some of which involved in growth and proliferation of cardiomyocytes and vascular smooth muscle cells (17). Furthermore, vitamin D was demonstrated to promote some important biological events important in 
Table 2. Patient characteristics compared according to the Werner classification

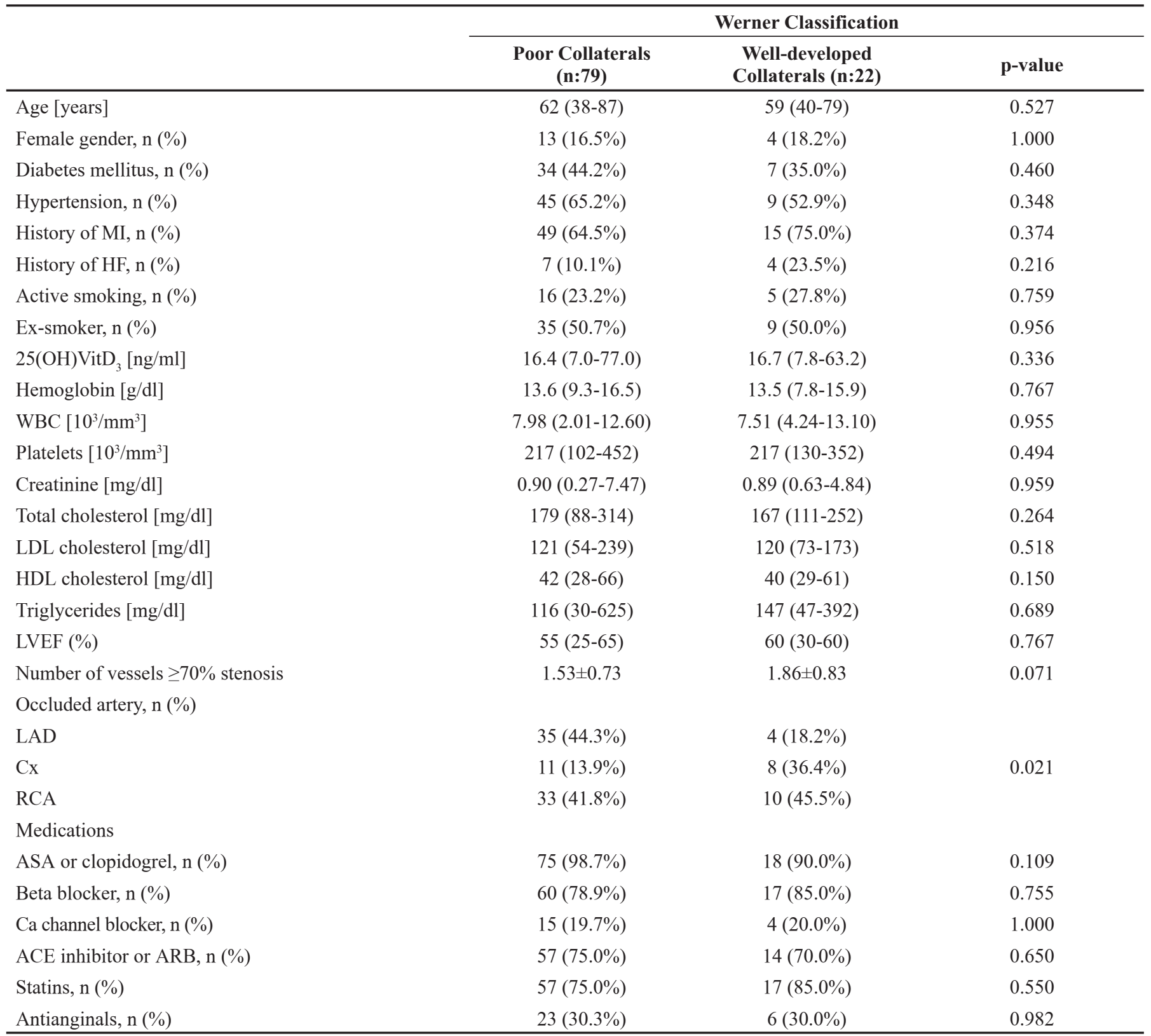

ACE: Angiotensin converting enzyme, ARB: Angiotensin receptor blocker, ASA: Acetylsalicylic acid, Cx: Circumflex artery, HF: Heart failure, LAD: Left anterior descending artery, LVEF: Left ventricular ejection fraction, MI: Myocardial infarction, RCA: Right coronary artery, WBC: White blood count

CCC development as leukocyte adhesion, increase in VEGF A expression, vascular smotth muscle cell proliferation and migration (18-20).

In the light of these experimental studies, clinical trials were warrented to confirm whether the level of vitamin D has an effect on the grade of coronary collaterals. In the literature, there are two clinical trials addressing the correlation between the level of vitamin D and the grade of CCC. Şahin et al. classified 214 patients who had at least one coronary artery with $>95 \%$ stenosis into two groups as poor collaterals (Rentrop 0-1) and well-developed collaterals (Rentrop 2-3) according to the Rentrop classification (21). In the multivariate analysis, lower levels of vitamin D was ascertained as an independent predictor of poor CCC. Moreover, Doğan et al. (22) grouped
188 patients with coronary CTO into two groups as poor collaterals (Rentrop 0-1) and well-developed collaterals (Rentrop 2-3) according to the Rentrop classification and multivariate logistic regression analysis showed that lower levels of $25(\mathrm{OH}) \mathrm{VitD}_{3}$ was an independent predictor of poor $\mathrm{CCC}$ in patients with $\mathrm{CTO}$.

In the present study, $\mathrm{CCC}$ was assessed according to not only the Rentrop but also the Werner classifications. Indeed, the Rentrop classification does not assess the collateral connection itself. It evaluates the filling effect in the recipient artery. Therefore, another collateral classification was unveiled by Werner. Werner classified collateral circulation according to collateral connections and upgraded his classification according to the diameter of collaterals again (23). Thus, 
the Werner classification directly assesses the collaterals. Therefore, in the present study, the relation between the level of $25(\mathrm{OH}) \mathrm{VitD}_{3}$ and the grade of CCC was evaluated via both the Rentrop and the Werner classifications.

In the present study, there was no correlation between the level of $25(\mathrm{OH}) \mathrm{VitD}_{3}$ and the grade of the CCC when assessed according to the Rentrop or the Werner classifications contrary to the findings of above-mentioned clinical studies. The results of the present study could be explained as follows: Type 2 diabetes mellitus, metabolic syndrome, smoking, renal dysfunction, oxidative stress and physical exercise are the unveiled factors effecting the development of CCC (2428). However, there may be unrevealed confounding factors which potentially have an effect on the development of CCC. Although it was shown that vitamin D has an effect on CCC in experimental studies, vitamin $\mathrm{D}$ is not the primary factor which promotes the development of CCC. As mentioned above, the parameters effecting NO and NO synthase may have a major role in the development of CCC. Therefore, vitamin D may not have an one to one effect on CCC development. Moreover, there may be potential confounding factors which have not revealed yet. Thus, this could be the reason why the present study did not find a correlation between the level of $25(\mathrm{OH}) \mathrm{VitD}_{3}$ and the grade of CCC.

\section{Study Limitations}

The major limitation of the present study is the number of patients enrolled in the study. Moreover, both classifications evaluating the $\mathrm{CCC}$ are based on angiography findings, therefore, visual. The coronary collaterals with a diameter of $<200 \mu \mathrm{m}$ are invisible even with new angiographic equipments. Therefore, coronary flow index which provides a functional information of coronary collaterals and which is the gold-standard method to assess the collaterals should have been utilized. In addition, the vitamin D level in a patient can fluctuate among different seasons in a year and this may lead to interindividual variability due to different levels of sunlight exposure. Therefore, it would have been better if the patient selection was only done in one season. Finally, exercise habits of patients could not be assessed due to the retrospective nature of the study. The level of physical exercise is important because it was stated that physical exercise has a positive effect on CCC, and this may act as a confounding factor in the present study.

\section{Conclusion}

Although a potential correlation between vitamin $\mathrm{D}$ and the grade of CCC was demonstrated in the experimental studies, we deem that there may not be a direct correlation (one-toone relationship) between the level of $25(\mathrm{OH}) \mathrm{VitD}_{3}$ and the grade of CCC due to the fact that vitamin D may not play a major role in the development of CCC and, moreover, there are various parameters having different levels of effects on the development of CCC.

\section{Acknowledgements}

We would like to thank to Işın Üreyen, MD for her contribution to the statistical analysis of the present study.

\section{References}

1. Holick MF. Vitamin D: importance in prevention of cancers, type 1 diabetes, heart disease and osteoporosis. Am J Clin Nutr 2004; 79: 362-71.

2. Burgaz A, Orsini N, Larsson SC, Wolk A. Blood 25-hydroxyvitamin D concentration and hypertension: a meta-analysis. J Hypertens 2011; 29: 636-45.

3. Giovannucci E, Liu Y, Hollis BW, Rimm EB. 25-hydroxyvitamin $\mathrm{D}$ and risk of myocardial infarction in men: a prospective study. Arch Intern Med 2008; 168: 117480 .

4. Pilz S, Marz W, Wellnitz B, Seelhorst U, FahrleitnerPammer A, Dimai HP, et al. Association of vitamin D deficiency with heart failure and sudden cardiac death in a large cross-sectional study of patients referred for coronary angiography. J Clin Endocrinol Metab 2008; 93: 3927-35.

5. Dobnig H, Pilz S, Scharnagl H, Renner W, Seelhorst U, Wellnitz B, et al. Independent association of low serum 25-hydroxyvitamin D and 1,25-dihydroxyvitamin D levels with all-cause and cardiovascular mortality. Arch Intern Med 2008; 168: 1340-9.

6. Sabia PJ, Powers ER, Ragosta M, SarembockI J, Burwell LR, Kaul S. An Association between collateral blood flow and myocardial viability in patients with recent myocardial infarction. N Engl J Med 1992; 327: 1825-31.

7. Ishihara M, Inoue I, Kawagoe T, Shimatani Y, Kurisu $\mathrm{S}$, Hata $\mathrm{T}$, et al. Comparison of the cardioprotective effect of prodromal angina pectoris and collateral circulation in patients with a first anterior wall acute myocardial infarction. Am J Cardiol 2005; 95: 622-5.

8. Rentrop KP, Thornton JC, Feit F, Van Buskirk M. Determinants and protective potential of coronary arterial collaterals as assessed by an angioplasty model. Am J Cardiol 1988; 61: 677-84.

9. Werner GS, Ferrari M, Heinke S, Kuethe F, Surber R, Richartz BM, et al. Angiographic assessment of collateral connections in comparison with invasively determined collateral function in chronic coronary occlusions. Circulation 2003; 107: 1972-7.

10. Carmeliet P. Mechanisms of angiogenesis and arteriogenesis. Nat Med 2000; 6: 389-95.

11. Werner GS, Ferrari M, Betge S, Gastmann O, Richartz BM, Figulla HR. Collateral function in chronic total coronary occlusions is related to regional myocardial function and duration of occlusion. Circulation 2001; 104: 2784-90.

12. Seiler C, Engler R, Berner L, Stoller M, Meier P, Steck $\mathrm{H}$, et al. Prognostic relevance of coronary collateral function: confounded or causal relationship? Heart 2013; 99: 1408-14.

13. Meier P, Hemingway H, Lansky AJ, Knapp G, Pitt B, Seiler C. The impact of the coronary collateral circulation on mortality: a meta-analysis. Eur Heart J 2012; 33: 614-21.

14. Cai WJ, Kocsis E, Luo X, Schaper W, Schaper J. Expression of endothelial nitric synthase in the vascular wall during arteriogenesis. Mol Cell Biochem 2004; 264: 193-200. 
15. Pittarella P, Squarzanti DF, Molinari C, Invernizzi M, Uberti F, Reno F. NO-dependent proliferation and migration induced by vitamin D in HUVEC. J Steroid Biochem Mol Biol 2015; 149: 35-42.

16. Grundmann M, Haidar M, Placzko S, Niendorf $R$, Darashchonak N, Hubel CA, et al. Vitamin D improves the angiogenic properties of endothelial progenitor cells. Am J Physiol Cell Physiol 2012; 303: 954-62.

17. Holick MF. Vitamin deficiency. N Engl J Med. 2007; 357 : 266-81.

18. Zehnder D, Bland R, Chana RS, Wheeler DC, Howie AJ, Williams MC, et al. Synthesis of 1,25-dihydroxyvitamin D-3 by human endothelial cells is regulated by inflammatory cytokines: a novel autocrine determinant of vascular cell adhesion. J Am Soc Nephrol 2002; 13: 621-9.

19. Rebsamen MC, Sun JX, Norman AW, Liao JK. 1 Alpha, 25-dihydroxyvitamin D-3 induces vascular smooth muscle cell migration via activation ofphosphatidylinositol 3-kinase. Circ Res 2002; 91: 17-24.

20. Cardus A, Parisi E, Gallego C, Aldea M, Fernandez E, Valdivielso JM. 1,25-dihydroxyvitamin D3 stimulates vascular smooth muscle cell proliferation through a VEGFmediated pathway. Kidney Int 2006; 69: 1377-84.

21. Sahin I, Okuyan E, Gungor B, Elitok A, Umman S, Umman B, et al. Lower vitamin D level is associated with poor coronary collateral circulation. Scand Cardiovasc J 2014; 48: 278-83.
22. Dogan Y, Sarli B, Baktir AO, Kurtul S, Akpek M, Sahin $\mathrm{O}$, et al. 25-Hydroxy-vitamin D level may predict presence of coronary collaterals in patients with chronic coronary total occlusion. Postepy Kardiol Interwencyjnej 2015; 11: 191-6.

23. Werner GS. The role of coronary collaterals in chronic total occlusions. Curr Cardiol Rev 2014; 10: 57-64.

24. Shen Y, Ding FH, Dai Y, Wang XQ, Zhang RY, Lu L, et al. Reduced coronary collateralization in type 2 diabetic patients with chronic total occlusion. Cardiovasc Diabetol 2018; 17 : 26.

25. Sezer M, Ozcan M, Okcular I, Elitok A, Umman S, Umman B, et al. A potential evidence to explain the reason behind the devastating prognosis of coronary artery disease in uraemic patients: renal insufficiency is associated with poor coronary collateral vessel development. Int J Cardiol 2007; 115: 366-72.

26. Turhan H, Yasar AS, Erbay AR, Yetkin E, Sasmaz H, Sabah I. Impaired coronary collateral vessel development in patients with metabolic syndrome. Coron Artery Dis 2005; 16: 281-5.

27. Uysal OK, Sahin DY, Duran M, Turkoglu C, Yildirim A, Elbasan Z, et al. Association between uric acid and coronary collateral circulation in patients with stable coronary artery disease. Angiology 2014; 65: 227-31.

28. Waltenberger J. Impaired collateral vessel development in diabetes: potential cellular mechanisms and therapeutic implications. Cardiovasc Res 2001; 49: 554-60. 